\title{
Palynology of the Genus Stachytarpheta Vahl. (Verbenaceae)
}

\author{
Olubukola ADEDEJI \\ Department of Botany, Obafemi Awolowo University, Ile-Ife, Osun State, Nigeria; oadedeji@oauife.edu.ng
}

\begin{abstract}
The exine morphology of pollen grains of Stachytarpheta indica (Linn.) Vahl, Stachytarpheta cayennensis (Rich.) Vahl and Stachytarpheta angustifolia (Mill.) Vahl is reported. This study was carried out with a light microscope. Pollen grains from fresh anthers were collected and aceolysed. Statistical analysis used to analyse the data collected include cluster analysis, correlation analysis, similarity and distance indices. The pollen grains are spheroidal to oblate to sub-oblate in shape. They are aperturate, both colpate and porate. Tricolpate types occur most frequently, acolpate, monocolpate, bicolpate and tetracolpate types less frequently. The multicolpate and multiporate attributes in all the species indicate that the genus is not primitive in evolutionary history and this species probably, evolved around in the same time. According to the size, the pollen grains of the genus falls into groups permagna (pollen diameter 100-200 $\mu \mathrm{m}$ ) and giganta (pollen diameter greater than $200 \mu \mathrm{m}$ ). S. cayennensis and S. anguistifolia belong to group permagna and S. indica only in the group giganta. This separates $S$. indica from the other two species. The large pollen grain size in the genus clearly supports the fact that the flowers in the genus are more insect-and-bird pollinated than wind pollinated. The similarity and distance indices of the species showed that $S$. cayennensis and $S$. angustifolia are the closest. S. indica is closer to $S$. angustifolia but farther from $S$. cayennensis.
\end{abstract}

Keywords: pollen grains, exine morphology, acolpate, multicolpate, multiporate

\section{Introduction}

The genus Stachyterpheta Vahl (Verbenaceae), known as "gervão", includes about 100 species widely distributed in tropical and subtropical America with few members in tropical Asia, Africa and Oceania, Barbola (2006). Members of the genus are herbs, shrubs or vines and sometimes trees with leaves usually opposite or whorled, simple or palmately compound or exstipulated (Hutchinson and Dalziel, 1963). The genus is represented by three species in West Africa and in Nigeria: S. cayannensis (Rich.) Vahl., S. indica (Linn.) Vahl. and S. angustifolia (Mill.) Vahl. (Hutchinson and Dalziel, 1963).

Stachytarpheta indica (L.) Vahl. is a slender-branched annual or perennial, erect subshrub, up to $200 \mathrm{~cm}$ tall. It is a weed of minor importance in rice fields, but may become a serious weed in pasture land, where it cannot be removed by mowing (Soerjani et al., 1987).

Stachyterpheta cayennensis (Rich.) Vahl. is an erect, sparsely-branched shrub (Stone, 1970). It is a common and important weed of crops, pastures, plantations, roadsides and wasteland, and also occurs as a minor weed in most other places. It grows best in deep, moist, fertile, disturbed soil (Swarbrick, 1997).

Stachyterpheta angustifolia (Mill.) Vahl. is an herbaceous annual, much-branched, up to $35 \mathrm{~cm}$ high, a ruderal of waste damp places throughout Senegal to West Cameroons and scattered elsewhere in tropical Africa and tropical America (Burkill, 1985).

All the Stachytarpheta species have been used ethnomedically as anti-diabetic, abortifacient, sedative, anti-hy- pertensive, anti-asthmatic and anti-fever (Schwontkowski, 1993; Balik, 1985; Duke and Vasquez, 1994). They are also used for dysentery, as vermifuge, anti-gonorrhoea and to cure cataract, sores in children's ear and also heart trouble. Various chemical constituents have been reported in the genus, e.g. flavones and flavonoids, saturated hydrocarbons, phenols, terpenes steroids, quinones, fatty acids such as stearic, oleic and palmitic acids (Duke, 1992).

The study of pollen is called palynology and is highly useful in paleoecology, paleontology, archeology and forensics. Almost all palynological discussions on plant relationship and phylogeny are based on the form, number, distribution and position of the apertures (Nair, 1971). These characters have been used in routine taxanomic work (Adedeji, 2005; Akinwusi and Illoh, 1996; Arogundade and Adedeji, 2009) as they provide one of the best taxonomic criteria, being often constant, not very variable and easily visible under a microscope (Sivarajan, 1991). According to Heywood (1968), the exine ornamentation patterns have been a great help in the identification and delimitation of taxa, especially at lower levels. The details of the exine are such that they can be used in plant identifications in much the same way that finger prints are used for the identification of criminals. The early history of palynological studies has been reviewed by Ducker and Knox (1985) and the bearing of palynology on Angiosperm phylogeny has been discussed at length by Walker and Doyle (1975) and its taxonomic implications by Erdtman (1952), Rudenko (1959), Sivarajan (1980b) and Rowley (1981). 
28

Reported work on the palynology of the genus Stachytarpheta is very sparse. Atkins (1991) reported the pollen morphology of the Brazilian species putative parents Stachytarpheta sericea Loes, and S. chamissonis Walp. and their resulting hybrid. There is no report on the pollen morphology of the three species of Stachytarpheta in Nigeria. This work aims to fill the knowledge gap in this genus.

\section{Materials and methods}

Pollen grains from fresh anthers of the three Stachytarpheta species S. cayennensis (Rich.) Vahl., S. indica (Linn.) Vahl. and S. angustifolia (Mill.) Vahl. were collected from various locations on the campus of Obafemi Awolowo University, Ile-Ife, Osun State, Nigeria, latitude $07^{\circ} 30^{\prime} \mathrm{N}$ and longitude $04^{\circ} 40^{\prime} \mathrm{E}$ for the palynological study. Pollen grains were collected from different flowers of the same species. These were acetolysed following the procedure of Erdtman (1960) by treatment with acetolysis mixture (Sulphuric acid and acetic anhydride).

Acetolysed pollen grains were mounted in glycerol and examined under the light microscope. Measurements of the diameter of pollen grain, wall thickness, pore diameter, distance between pores were made and number of pores were counted for twenty five pollen grains for each taxon. Photomicrographs of the acetolysed pollen grains were taken with the aid of Amscope Digital Camera mounted on a light research microscope.

For data analysis, the mean and standard error of the values obtained from the attributes were calculated using PAST Statistical Packages. The attributes were analysed for correlation (correlation analysis), and also for calculating the similarity and distance indices of the three species in the genus Stachytarpheta. Cluster diagram of the values of the attributes was also prepared.

\section{Results}

The pollen grains of the three species of Stachytarpheta studied are spheroidal (Fig. 2A and E) to oblate (Fig. 2D) to sub-oblate (Fig. 2C). Both colpi (furrows) and pores were present.

\section{S. indica}

Acolpate (Fig. 2A), monocolpate (Fig. 3A), bicolpate (Fig. 3B), tricolpate (Fig. 4A and B), tetracolpate (Fig. 3F) pollen grains were present. The mean diameter of the pol-

Tab. 1. Summary of the quantitative pollen grain studied attributes; minimum (mean \pm standard error) maximum

\begin{tabular}{cccccc}
\hline Species & $\begin{array}{c}\text { Pollen grain } \\
\text { diameter }(\mu \mathrm{m})\end{array}$ & $\begin{array}{c}\text { Pollen wall } \\
\text { thickness }(\mu \mathrm{m})\end{array}$ & $\begin{array}{c}\text { Pore diameter } \\
(\mu \mathrm{m})\end{array}$ & $\begin{array}{c}\text { Distance between } \\
\text { pores }(\mu \mathrm{m})\end{array}$ & Number of pores \\
\hline S. indica & $165(209.6 \pm 4.44) 228$ & $2.5(5.5 \pm 0.5) 8.75$ & $3.75(9.17 \pm 0.80) 13.75$ & $1.25(4.5+0.60) 8.75$ & $185(230.13 \pm 11.13) 305$ \\
S. angustifolia & $120(159.67 \pm 5.07) 190$ & $2.5(4.83 \pm 0.30) 6.25$ & $3.75(8.25 \pm 0.42) 10$ & $1.25(2.95 \pm 0.37) 5.5$ & $131(182.93 \pm 6.44) 211$ \\
S. cayennensis & $90(116.47 \pm 3.66) 148$ & $2.5(3.83+0.26) 5.0$ & $2.5(5.17 \pm 0.40) 7.5$ & $1.25(1.92 \pm 0.21) 3.75$ & $96(129.07 \pm 6.00) 172$ \\
\hline
\end{tabular}

Tab. 2. Correlation analysis of the pollen grain studied attributes (units of attributes in $\mu \mathrm{m}$ )

\begin{tabular}{cccccc}
\hline & $\begin{array}{c}\text { Pollen } \\
\text { grain } \\
\text { diameter }\end{array}$ & $\begin{array}{c}\text { Pollen } \\
\text { wall } \\
\text { thickness }\end{array}$ & $\begin{array}{c}\text { Pore } \\
\text { diameter }\end{array}$ & $\begin{array}{c}\text { Distance } \\
\text { between } \\
\text { pores }\end{array}$ & $\begin{array}{c}\text { Number } \\
\text { of pores }\end{array}$ \\
\hline $\begin{array}{c}\text { Pollen grain } \\
\text { diameter }\end{array}$ & $\mathrm{X}$ & & & & \\
$\begin{array}{c}\text { Pollen wall } \\
\text { diameter } \\
\text { Pore }\end{array}$ & 0.927752 & $\mathrm{X}$ & & & \\
$\begin{array}{c}\text { diameter } \\
\text { Distance }\end{array}$ & 0.94114 & 0.932355 & $\mathrm{X}$ & & \\
$\begin{array}{c}\text { between pores } \\
\text { Number } \\
\text { of pores }\end{array}$ & 0.997319 & 0.923684 & 0.91388 & $\mathrm{X}$ & \\
\hline
\end{tabular}

Tab. 3. Similarity and distance indices of the studied species

\begin{tabular}{cccc}
\hline & S. cayennensis & S. angustifolia & S. indica \\
\hline S.cayennensis & $\mathrm{X}$ & & \\
S. angustifolia & 3833.4 & $\mathrm{X}$ & \\
S. indica & 9734.1 & 5900.88 & $\mathrm{X}$ \\
\hline
\end{tabular}

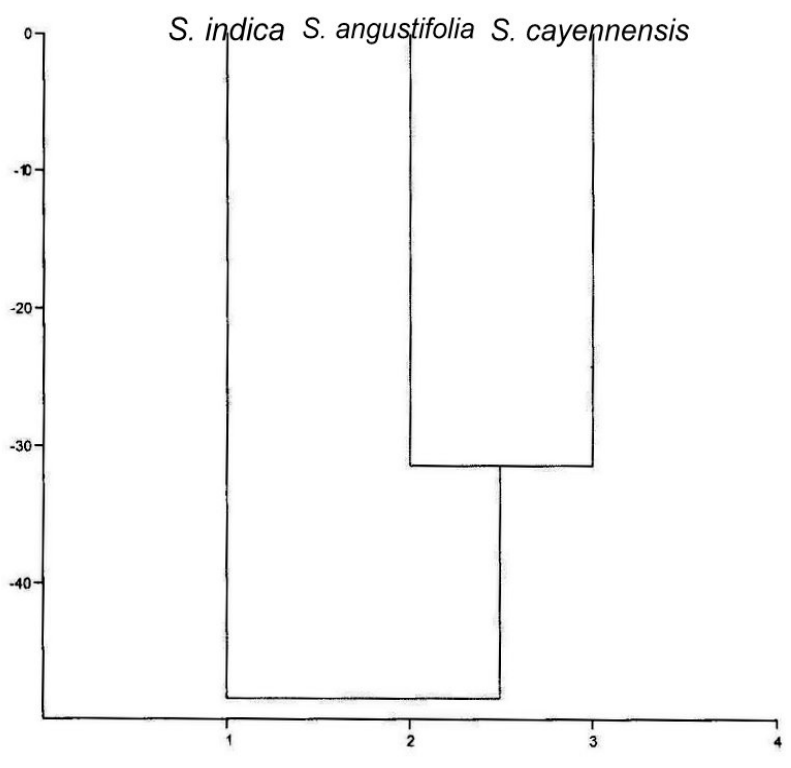

Fig. 1. Dendrogram of the pollen grain attributes of the Stachytarpheta studied species 

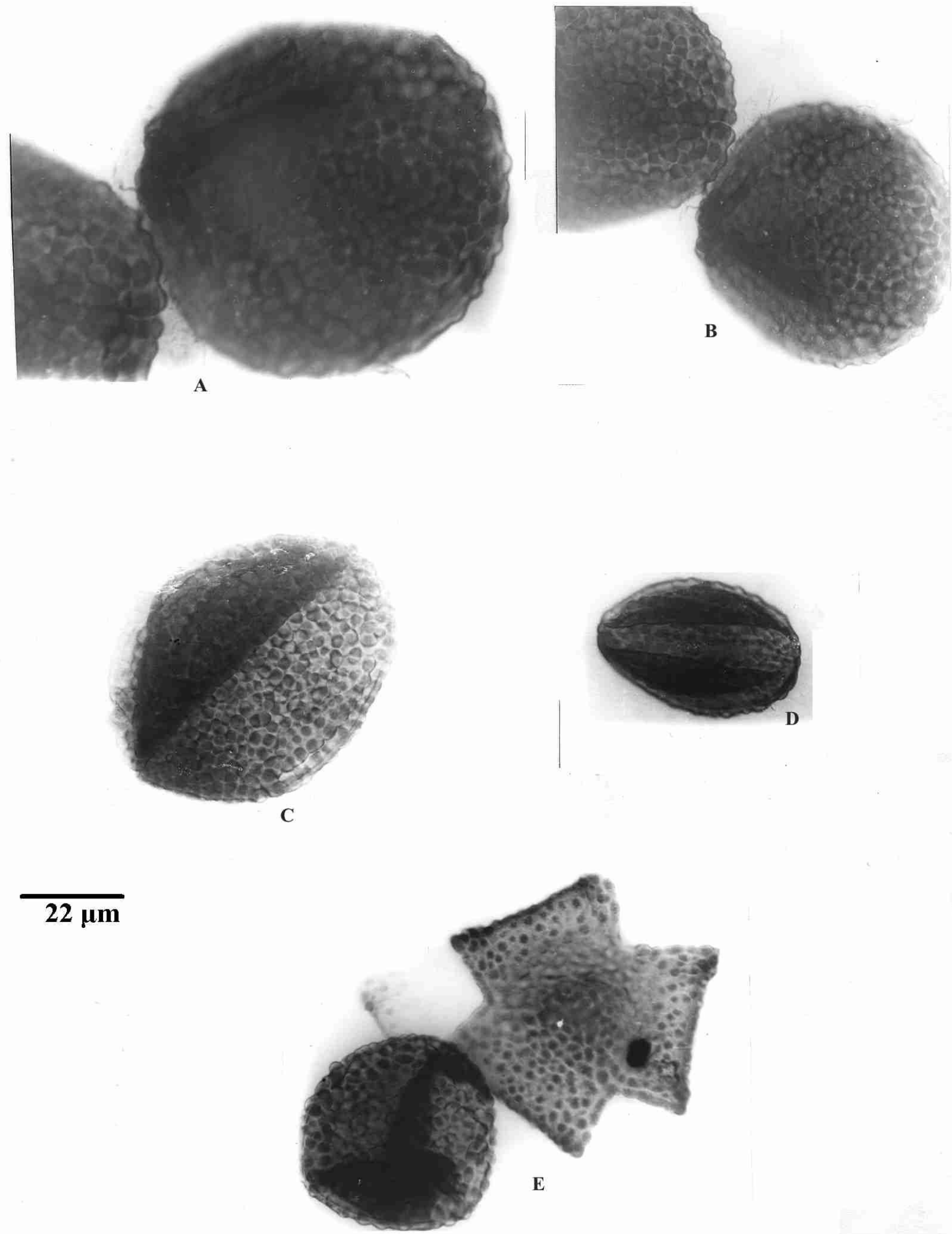

Fig. 2. A. Acolpate pollen grain in S. indica; B. Acolpate pollen grain in S. angustifolia; C. Acolpate pollen grain in S. angustifolia; D. Acolpate pollen grain in S. cayennensis; E. Acolpate and tricolpate pollen grain in S. cayennensis 
30
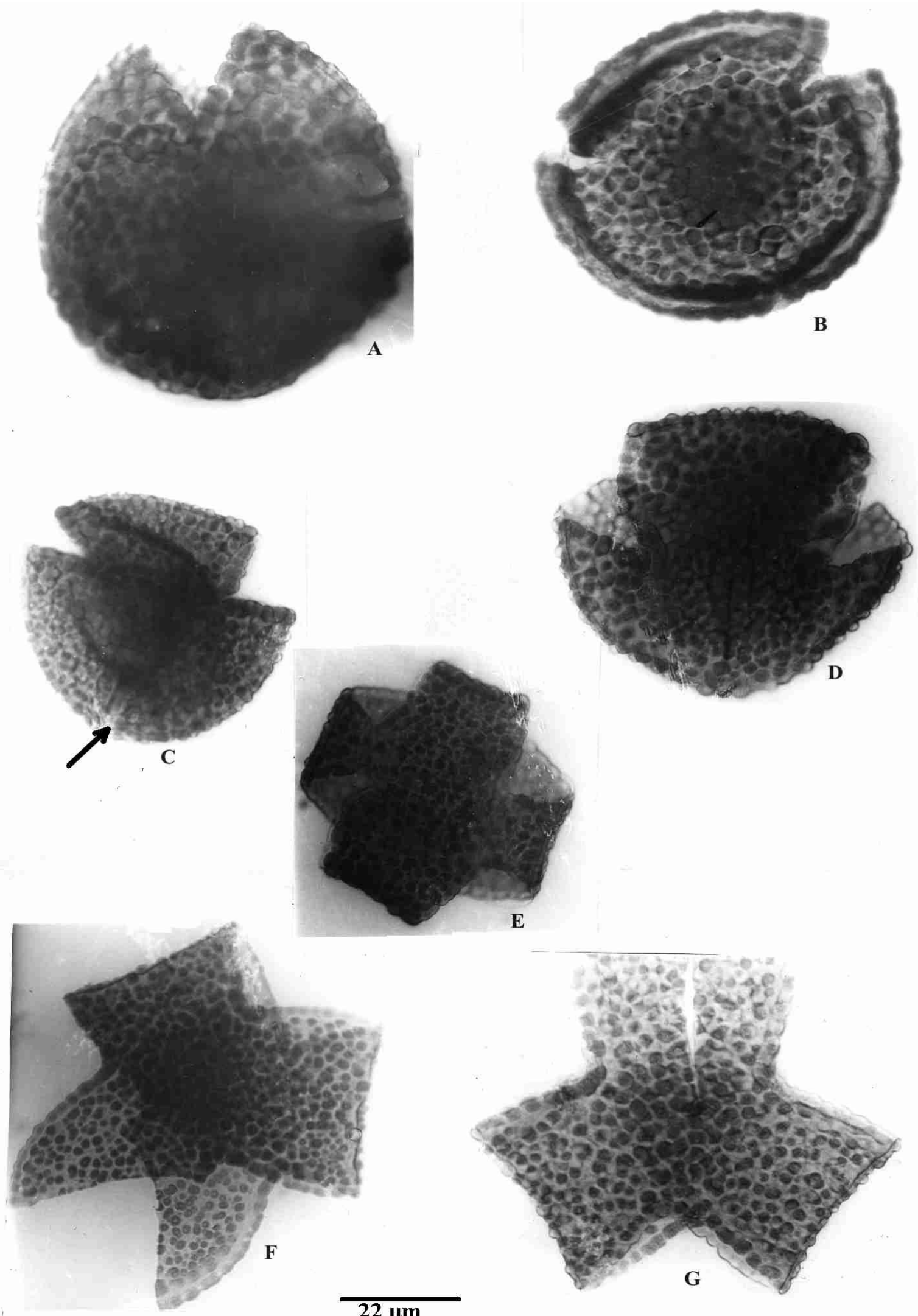

Fig. 3. A. Monocolpate pollen grain in $S$. indica and $S$. angustifolia; B. Bicolpate pollen grain in S.indica and $S$. cayennensis; C. Tricolpate pollen grain (arrow on $3^{\text {rd }}$ furrow colpus, slightly opened (observed in all the species); D. Bicolpate pollen grain in $S$. angustifolia; E. Tetracolpate pollen grain in S. cayennensis; F. Tetracolpate pollen grain in $S$. indica; G. Tetracolpate pollen grain in $S$. angustifolia 

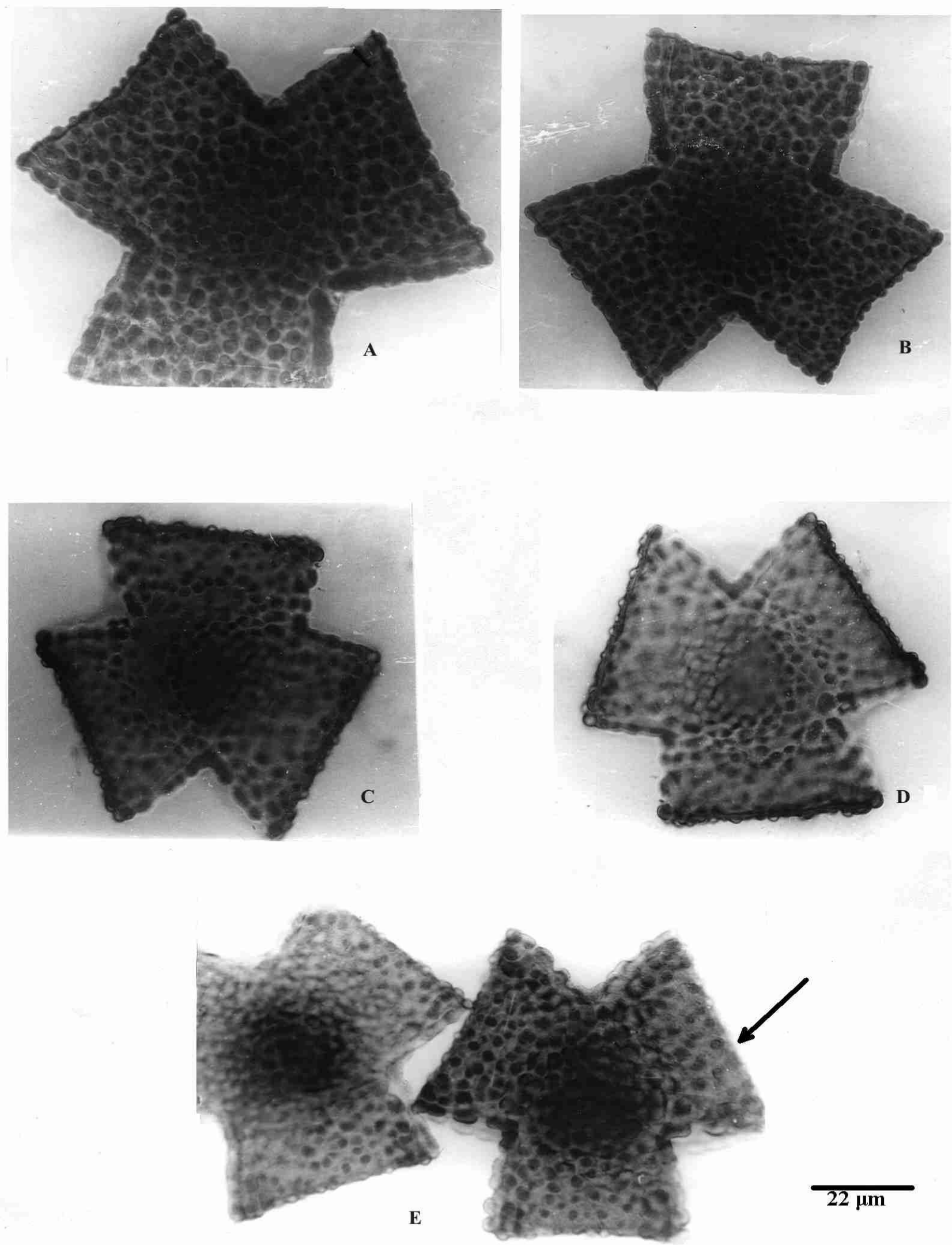

Fig. 4. Tricolpate pollen grains in the Stachytarpheta studied species; A and B: S. indica; C and D: S. angustifolia; E: S. cayennensis (arrow shows whole tricolpate pollen grain) 
32

len grains is $209.6 \mu \mathrm{m} \pm 4.44 \mu \mathrm{m}$, mean pollen wall thickness is $5.5 \pm 0.5 \mu \mathrm{m}$, mean pore diameter, $9.17 \pm 0.80 \mu \mathrm{m}$, mean distance between pores, $4.5 \pm 0.60 \mu \mathrm{m}$, number of pores were between 185-305 (Tab. 1).

\section{S. angustifolia}

Acolpate (Fig. 2B and C), monocolpate (Fig. 3A), Bicolpate (Fig. 3D), tricolpate (Fig. 4C and D), tetracolpate (Fig. 3G) pollen grains were present. Mean diameter of the pollen grains is $159.67 \pm 5.07 \mu \mathrm{m}$, mean pollen wall thickness is $4.83 \pm 0.30$, mean pore diameter is $8.25 \pm 0.42 \mu \mathrm{m}$, mean distance between pores is $2.95 \pm 0.37 \mu \mathrm{m}$, number of pores were range between 131-211 (Tab. 1).

\section{S. cayennensis}

Acolpate (Fig. 2D and E), monocolpate rare to few, bicolpate (Fig. 3B), tricolpate (Fig. 2E and 3E), tetracolpate (Fig. 3E), pollen grains were occur. Mean diameter of pollen grain is $116.47 \pm 3.66 \mu \mathrm{m}$, pollen wall thickness is $3.83 \pm 0.26 \mu \mathrm{m}$, mean pore diameter is $5.17 \pm 0.40 \mu \mathrm{m}$, distance between pores is $1.92 \pm 0.21 \mu \mathrm{m}$, number of pores were between 96-172 (Tab. 1).

\section{Statistical analysis}

The dendrogram from the cluster analysis (Fig. 1) divides the three species into two groups, S. angustifolia and $S$. indica together in one group and $S$. cayennensis only in the other group. Tab. 2 shows the correlation analysis of the attributes of the three species studied. Pollen diameter and distance between pores, pollen diameter and number of pores, pollen wall thickness and number of pores have the highest values. Based on all the attributes studied, the similarity and distance indices of the Stachytarpheta studied species was noticed in Tab. 3 .

\section{Discussion}

The pollen wall has been a subject of considerable attention, especially in an attempt to establish the evolutionary history of angiosperms (Singh, 2006). The pollen grains of the studied species of the genus Stachytarpheta were spheroidal to oblate to sub-oblate in shape, most especially when acolpate (i.e. without apertures), when tricolpate, they appeared T-shaped.

Pollen grains of the genus are both colpate and porate. It is known that the earliest angiosperm pollen were without an opening, that is acolpate, the monocolpate types developing later, multicolpate and multiporate pollen grains arising at a later stage (Singh, 2006). This study reveals that the pollen grains of the genus Stachytarpheta are acolpate, monocolpate, bicolpate, tricolpate occurring at the highest frequency in all the species, and tetracolpate (i.e. multicolpate). All the types mentioned were found occurring in all the species, though monocolpate occurred at a very low frequency in $S$. cayennensis. Number of pores ranged from 185-305 in S. indica, 131-211 in S. angustifolia, 96-172 in S. cayennensis. The multicolpate and multiporate attributes of this genus give multiple opportunities for pollen tube to pass through the wall during pollination. The multicolpate and multiporate attributes also denote that the genus is not primitive in evolutionary history and that the three species in the genus probably evolved around the same time.

Pollen grains of $S$. indica were larger than those of $S$. angustifolia and $S$. indica. Pollen wall thickness, pore diameter, distance between pores, number of pores also followed the same trend, that was, higher in $S$. indica, followed by $S$. angustifolia and least in $S$. cayennensis (Tab. 1). Erdtman (1952) classified pollen grains into groups according to sizes, perminuta (diameter less than $10 \mu \mathrm{m}$ ), minuta (diameter 10-25 $\mu \mathrm{m}$ ), media (diameter 25-50 $\mu \mathrm{m}$ ), magna (diameter 50-100 $\mu \mathrm{m}$ ), permagna (diameter 100$200 \mu \mathrm{m}$ ), giganta (dimater greater than $200 \mu \mathrm{m}$ ). This classification reveals that the pollen grains of the genus Stachytarpheta are in the groups permagna and giganta. $S$. cayennensis and $S$. angustifolia belong to the group permagna while $S$ indica belongs to the group giganta. This clearly separates $S$. indica from the other two species. The pollen of anemophilous plants is usually small, while that of insect-and-bird-pollinate plant is usually large (Singh, 2006). The large pollen grain size in the species studied, clearly supports the fact that the flowers in the genus Stachytarpheta are more insect-and-bird-pollinated than wind pollinated. This further authenticates the work of Barbola et al. (2006) on the floral biology of Stachytarpheta maximiliani Scham. and its floral visitors which reported that many species of beetles, hemipterans, flies, wasps, bees and butterflies visit their flowers, but bees and butterflies are the most frequent visitors. According to the report, the flowers of $S$. maximiilani are intensively visited by different insect groups since the first hours of the morning until the afternoon. The tubular flower requires specialized nectar-feeding insects (Faegri and Van der Pijl, 1979; Ormond et al., 1993; Antonini et al., 2005). So, visitors with long thin tongues could collect nectar at the corolla basis more easily, and pollen as well, when compared to short-tongue insects (Barbola et al., 2006).

Atkins (1991) reported pollen grain diameter of Stachytarpheta sericea and S. chamissonis and the hybrid from the crossing of the two species to be between 78 and $175 \mu \mathrm{m}$. The values for pollen grain diameter obtained for $S$. cayennensis and $S$. angustifolia in this study are at par with those obtained by Atkin (1991), but the pollen grain of $S$. indica are distinctly larger. He reported pollen wall thickness of the species he studied to be between 5 and 10 $\mu \mathrm{m}$, while pollen wall thickness is between 2.5 and 8.75 $\mu \mathrm{m}$ in the three species reported in this work. In addition, monocolpate and tetracolpate pollen grains reported in this work were not reported for $S$. sericea and $S$. chamissonis and their hybrid. 
Cluster diagram (Fig. 1) based on all the attributes studied, separates $S$. indica from $S$. angustifolia and $S$. cayennensis. The correlation analysis of the studied attributes (Tab. 2), showed that pollen diameter is highly correlated with distance between pores and numbers of pores in the taxonomy of the genus and also pollen wall thickness is highly correlated with number of pores. The similarity and distance indices of the three species (Tab. 3) showed that the highest similarity or closeness (i.e. shortest distance in$\mathrm{dex}$ ) is between $S$. cayennensis and $S$. angustifolia, followed by $S$. angustifolia and $S$. indica. In other words, $S$. cayennensis and $S$. angustifolia are the closest, $S$. indica is closer to $S$. angustifolia but farther from $S$. cayennensis.

\section{References}

Adedeji, O. 2005. Pollen morphology of the three species of the genus Emilia Cass. (Asteraceae) from Nigeria. Thaiszia Journal of Botany 15:1-9.

Akinwusi, O. and H. C. Illoh (1996). Pollen grain morphology of some species of Hibiscus Linn. Nigerian Journal of Botany 9:9-14.

Antonini, Y., H. G. Souza, C. M. Jacobi and F. B. Mury (2005). Diversidade e comportamento dos insetos visitantes florais de Stachytarpheta glabra Cham. (Verbenaceae), em uma àrea de campo ferruginoso, Ouro Preto, MG. Neotropical Entomology 34:555-564.

Arogundade, O.O. and O. Adedeji (2009). Pollen morphology of three species and a variety of Ocimum Linn. (Lamiaceae) in Southwestern Nigeria. Journal of Science and Technology 29(3):1-7.

Atkins, S. (1991). Stachytarpheta sericea Atkins (Verbenaceae) and Its Hybrid with S. chamissonis Walp. Kew Bulletin 46(2):281-289.

Balik, M. J. (1985). Note on some medicinal and poisonous plants of Amazonia Peru, Advance in Economic Botany 1:1-8.

Barbola, I. F., S. Laroca, M. C. Almeida and E. A. Nascimento (2006). Floral biology of Stachytarpheta maximiliani Scham. (Verbenaceae) and its floral visitors. Revista Brasileira de Entomologia 50(4):498-504.

Burkill, H. M. (1985). The useful plants of West Tropical Africa, $2^{\text {nd }}$ Edition. Royal Botanic Gardens, Kew. 3:19-27.

Ducker, S. C. and R. B. Knox (1985). Pollen and pollination: a historical review. Taxon 34:401-419.

Duke, J. A. (1992). CRC Handbook of Phytochemical constituents of CRAS herbs and other economic plants, CRC Press, Boca Rotan, FLC, USA.
33

Duke,J.A.and R.V. Martinez (1994). Amazonia Ethnobotanical Dictionary (Peru) CRC Press, Boca Roton FL, USA.

Erdtman, G. (1952). Pollen Morphology and Plant Taxonomy. Chronica Botanica Co., Waltham, Mass., U.S.A.

Erdtman, G. (1960). The acetolysis method in a revised description. Svensk Botanisk Tidskrift, Lund 54(4):561564.

Faegri, K. and Van der Pijl (1979). The principles of pollination ecology. Oxford, Pergamon Press, $3^{\text {rd }}$ ed.

Heywood, V. H. (1967). Plant Taxonomy, London.

Hutchinson, J. and J. M. Dalziel (1963). Flora of West Tropical Africa. Second edition Vol. 11 Crown Agents, London.

Nair, P. K. K. (1971). Pollen Morphology of Angiosperms. New York.

Ormond, W. T., M. C. B. Pinheiro, H. A. Lima, M. C. R. Correia and M. L. Pimenta (1993) Estudo das recompensas florais das plantas da Restinga de Maricá - itaipuaçu, RJ 1 Nectariferas. Bradea 6:179-195.

Rowley, J. R. (1981). Pollen wall characters with emphasis on applicability. Nord. J. Bot. 1:357-380.

Rudenko, F.E. (1959). The significance of the male gametophyte in the taxonomy of Angiosperms. Bot. Zh. 44:1467-1475.

Schwontkowski, D. (1993). Herbs of the amazo -Traditional and common uses, Science Student Brain Trust Publishing, New York.

Singh, G. (2006). Plant Systematics, Theory and Practice, $2^{\text {nd }}$ Edition, Oxford and IBH Publishing Co. New Delhi.

Sivarajan, V. V. (1980)b. Contribution of palynology to Angiosperm systematics. Adv. Poll. Spore Res. 57:256-260.

Sivarajan, V. V. (1991). Sources of Taxonomic characters, 149150pp. In: Robson, N. K. P. (Eds.). Introduction to the Principles of Plant Taxonomy. $2^{\text {nd }}$ Edition. Oxford and IBH Publishing Co. New Delhi.

Soerjani, M., A. J. G. H. Kostermans and G. Tjitrosoepomo (1987). Weeds of Rice in Indonesia. Balai Pustaka, Jakarta.

Stone, B. C. (1970). The flora of Guam. Micronesica 6:1-659.

Swarbrick, J. T. (1997). Weeds of the Pacific Islands. Technical paper number 209. South Pacific Commission, Noumea, New Caledonia.

Walker, J. W. and J. A. Doyle (1975). The bases of angiosperm phylogeny: Palynology. Ann. Miss.Bot. Gard. 62:664-723. 